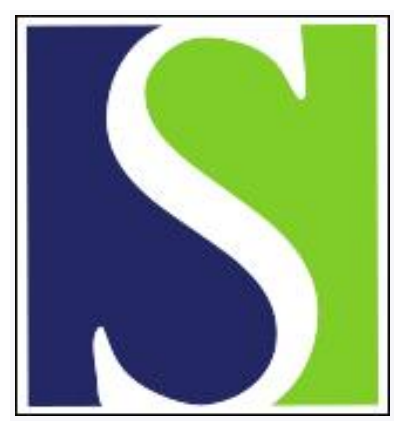

Scand J Work Environ Health 1976;2(1):21-26

https://doi.org/10.5271/sjweh.2825

Issue date: Mar 1976

Urinary mandelic acid concentration after occupational exposure to styrene and its use as a biological exposure test. by Engström K, Härkönen H, Kalliokoski P, Rantanen J

The following article refers to this text: 1980;6(2):158-160

Key terms: biological exposure test; exposure test; mandelic acid; mandelic acid concentration; occupational exposure; styrene; urinary concentration; urinary mandelic acid concentration

This article in PubMed: www.ncbi.nlm.nih.gov/pubmed/1273564 


\title{
Urinary mandelic acid concentration after occupational exposure to styrene and its use as a biological exposure test
}

by KERSTIN ENGSTRÖM, M.Sc., HANNU HÄRKÖNEN, M.D., PENTTI KALLIOKOSKI, M.Sc. (Eng.), and JORMA RANTANEN, M.D. ${ }^{1}$

\begin{abstract}
ENGSTRÖM, K., HÄRKONEN, H., KALLIOKOSKI, P. and RANTANEN, J. Urinary mandelic acid concentration after occupational exposure to styrene and its use as a biological exposure test. Scand. j. work environ. \& health 2 (1976) 21-26. Excretion of mandelic acid from workers in the reinforced polyester plastic industry was studied with the determination of urinary mandelic acid concentrations. The styrene exposure level at the workplaces was evaluated with measurements of the styrene concentration in the ambient air. Three different groups (I, II and III) were studied. In group I [ $\mathrm{n}=9$, median of the time-weighted average (TWA) of exposure $=23 \mathrm{ppm}$ of styrene, postexposure observation period $=64 \mathrm{~h}$ ] two excretion slopes were observed, the first with a median half-time of $9.4 \mathrm{~h}$ (postexposure period $0-18 \mathrm{~h}$ ) and a second with a median half-time of $16.6 \mathrm{~h}$ (postexposure period $19-64 \mathrm{~h}$ ). For group II $(\mathrm{n}=9$, median TWA exposure $=248 \mathrm{ppm}$, postexposure observation period $=15 \mathrm{~h}$ ) a half-time of $6.4 \mathrm{~h}$ was found. These results suggest that the excretion rate of mandelic acid is dependent on the styrene exposure level. In addition the mandelic acid concentrations of 29 workers (group III) before and after the work shift were analyzed. The urinary mandelic acid concentrations of groups I, II and III, sampled immediately after the 8-h work shift, correlated with the 8-h TWA of styrene exposure $(\mathrm{n}=47, \mathrm{r}=0.93$ ). Accordingly about $2,300 \mathrm{mg}$ of mandelic acid per gram of creatinine corresponded to $100 \mathrm{ppm}$ of styrene.
\end{abstract}

Key Words: styrene, mandelic acid, exposure test.

Until recently styrene was considered a substance with low acute toxicity (9). However, modern literature indicates a possible relationship between styrene exposure and transient or permanent disturbances in the central nervous system $(2,8,14)$. In addition the use of styrene is increasing in several plastic producing industries, especially in plants manufacturing products of reinforced polyester plastic. Thus the control of occupational

1 Institute of Occupational Health, Helsinki, Finland.

Reprint requests to: Ms. Kerstin Engström, Institute of Occupational Health, Regional Unit of Turku, Kerttulinkatu 5, FIN-20500 Turku 50, Finland. exposure to styrene is becoming more important, and accurate knowledge of styrene metabolism is needed.

The measurement of the main metabolites of styrene in man, mandelic acid and phenylglyoxylic acid, has already been proposed as an indicator of styrene exposure $(3,10,11,18)$. Recently new methods that are more specific and more sensitive have been developed for the determination of these metabolites $(4,7$, 19). The new methods have improved the possibilities for studying the excretion of styrene metabolites.

In the present study we measured postexposure concentrations of urinary mandelic acid from workers occupationally ex- 
posed to styrene and calculated the halftimes of the mandelic acid concentrations. We also correlated the 8-h time-weighted average (TWA) of exposure to styrene with the mandelic acid concentrations of the urinary samples taken at the end of $8-\mathrm{h}$ styrene exposure.

\section{MATERIAL AND METHODS}

\section{Subjects}

The 47 subjects came from 13 factories manufacturing products of reinforced polyester plastic. In all cases the workers spread the polyester resin by hand. For the study the workers were divided into three groups (I, II, III) according to the length of the observation period and the level of the styrene exposure. Group characteristics are presented in table 1 .

Information on the workers' health was obtained through the use of a questionnaire. None of the workers reported a chronic disease of the lungs, liver, or kidneys.

The subjects were requested to refrain from drinking alcoholic beverages and to avoid excessive sauna bathing during the observation period, but no other specific instructions were given.

\section{Exposure}

Styrene in the ambient air was measured by pumping air from the breathing zone of the workers through charcoal sampling tubes with a personal sampling pump (MSA). The adsorbed styrene was extracted from the charcoal with dimethyl formamide and analyzed by gas chromatography (13). The results were timeweighted to $8 \mathrm{~h}$. The measurements were performed on a normal work day, but not on a Monday.

\section{Collection of urine samples and determination of urinary mandelic acid}

The subjects of groups I and II provided urine samples at the beginning of an 8-h work shift, $4 \mathrm{~h}$ later, again at the end of the shift, and thereafter 4,8 and $15 \mathrm{~h}$ after exposure was terminated. Group I continued to collect urine samples at every miction for $64 \mathrm{~h}$ after the end of exposure (during the weekend). Urine samples were collected from group III before and at the end of the 8-h work day only.

All urine samples were preserved at $+4^{\circ} \mathrm{C}$ and analyzed within 1 week. Mandelic acid was extracted from the urine with diethylether. It was silylated and analyzed by gas chromatography (7). Results were corrected for a specific gravity of 1.018 according to the formula $f_{k}=$ $(1.018-1) /(Q$ sample-1) or calculated as milligrams of mandelic acid per gram of creatinine. The determination of creatinine was carried out with a Technicon AutoAnalyzer (Jaffés color reaction).

\section{Statistical methods}

The concentrations of mandelic acid were plotted on a semilogarithmic scale. Linear regression lines were calculated with the method of the least square fitting. Biological half-times ( $\mathrm{T} 1 / 2=$ time during which the concentration of mandelic acid decreased by $50 \%$ ) were estimated from the regression lines. The significance of the differences between the half-times was examined with the Wilcoxon and the sign test. The Pearson correlation coefficient was calculated between the urinary mandelic acid concentration and the measured styrene exposure.

\section{RESULTS}

\section{Excretion of mandelic acid}

The mandelic acid concentration of the urine samples began to rise after the beginning of exposure and was highest at the end of the 8-h shift. The individual excretion curves of groups I and II are presented in fig. 1; and the numerical results, in table 2.

In group I (observation period $64 \mathrm{~h}$ ) two slopes were observed, the first for a postexposure time of $0-18 \mathrm{~h}$ and the second for a postexposure time of $19-64 \mathrm{~h}$. The difference between these half-times was statistically significant at the 0.05 level (sign test). 


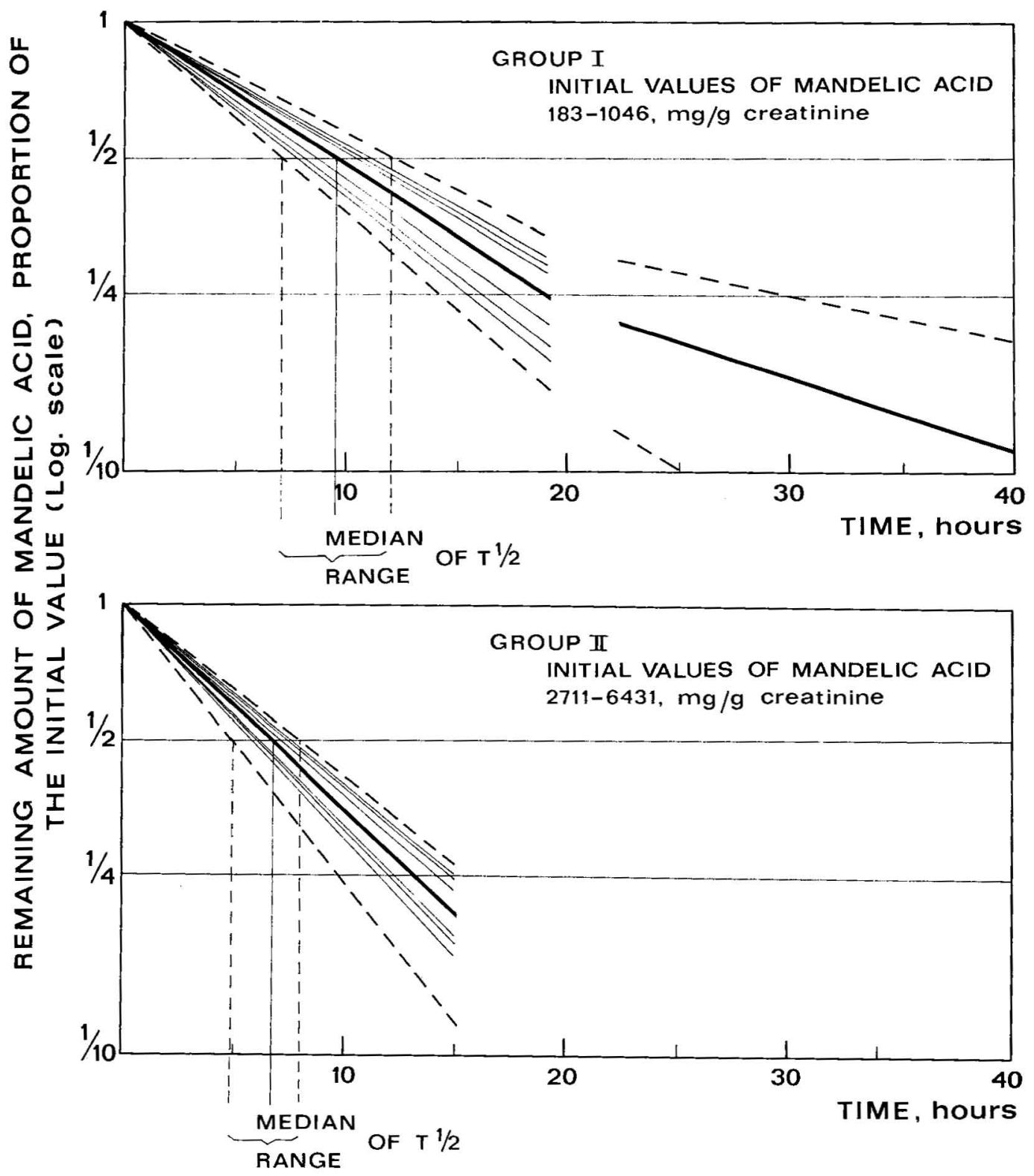

Fig. 1. Proportional elimination of styrence measured as urinary mandelic acid concentration. The values are chosen so that the maximum concentration corresponds to 1 .

Table 1. Characterisctics of the exposed groups.

\begin{tabular}{|c|c|c|c|c|c|c|c|}
\hline \multirow{2}{*}{ Group } & \multirow{2}{*}{$\begin{array}{c}\text { Total } \\
\text { observation } \\
\text { period (h) }\end{array}$} & \multicolumn{2}{|c|}{ Number } & \multicolumn{2}{|c|}{ Age (yr) } & \multicolumn{2}{|c|}{ Duration of exposure (yr) } \\
\hline & & Males & Females & Median & Range & Median & Range \\
\hline$I$ & 72 & 7 & 2 & 29 & $24-45$ & 3 & $0.1-10$ \\
\hline II & 24 & 9 & 一 & 31 & $17-46$ & 3 & $0.1-6$ \\
\hline III & 9 & 22 & 7 & 27 & $18-55$ & 2.5 & 2 days -10 yr \\
\hline
\end{tabular}


Table 2. Results of the excretion studies.

\begin{tabular}{|c|c|c|c|c|c|}
\hline \multirow{2}{*}{ Group } & \multirow{2}{*}{$\begin{array}{l}\text { Postexposure } \\
\text { observation } \\
\text { period (h) }\end{array}$} & \multicolumn{2}{|c|}{ 8-h TWA (ppm) } & \multicolumn{2}{|c|}{ Mandelic acid half-time (h) } \\
\hline & & Median & Range & Median & Range \\
\hline I & $0-18$ & 23 & $4-94$ & 9.4 & $7.1-11.9$ \\
\hline I & $19-64$ & 23 & $4-94$ & 16.6 & $9.8-56.0$ \\
\hline II & $0-15$ & 248 & $155-291$ & 6.4 & $4.7-7.6$ \\
\hline III & - & 52 & $6-120$ & - & - \\
\hline
\end{tabular}

The half-time of mandelic acid excretion for the first postexposure period of group I differed significantly (Wilcoxon, $Z=3.44, p<0.001$ ) when it was compared with that of group II. This result indicates that the half-time of mandelic acid excretion is dependent on the exposure level of styrene.

Correlation of the TWA of styrene exposure with mandelic acid concentrations

A high positive correlation was observed between the mandelic acid concentration of urine samples taken immediately after the end of the work shift and the 8-h TWA of styrene exposure (groups I, II and III). If one considers the mandelic acid concentrations of the urinary prework samples and the fact that the half-time for the postexposure period is about $16 \mathrm{~h}$, it is apparent that the correct postwork values for mandelic acid concentration will be obtained when $70 \%$ of the prework concentrations is subtracted from the postwork values. The corrected concentrations, expressed as milligrams per gram of creatinine, correlated highly significantly with the 8-h TWA of styrene exposure ( $\mathrm{n}=47, \mathrm{r}=0.93$ ) (fig. $2 \mathrm{~A}$ ). A nonlinear regression agreed well with the observed differences in the half-times of groups I and II, namely, a shorter half-time at higher exposure levels (table 2).

A more practical calculation is the correlation of total mandelic acid concentration (without considering the prework values) and the 8-h TWA of styrene exposure. Such a calculation produced a correlation coefficient of 0.93 (fig. $2 \mathrm{~b}$ ). Thus the two correlation coefficients do not differ.
In both cases styrene exposure correlated better with mandelic acid concentration when it was expressed as milligrams per gram of creatinine than when it was adjusted to a constant specific gravity of 1.018 , e.g., a correlation coefficient of 0.87 was obtained between the 8-h TWA and the total mandelic acid concentration when the latter was adjusted to a constant specific gravity of $1.018(\mathrm{y}=56.9+25.69 \mathrm{x}$ $\left.-0.03931 \mathrm{x}^{2} \pm 732.1\right)$.

\section{DISCUSSION}

\section{Excretion of mandelic acid}

Insignificant amounts of absorbed styrene (traces to $2.9 \%$ ) are eliminated in exhaled air $(1,3,5,6)$. The remaining styrene is mainly metabolized to mandelic and phenylglyoxylic acids by the hepatic microsomal system (15), about $50-85 \%$ being excreted as mandelic acid $(1,3)$. Ikeda and Imamura (12) have observed elevated hippuric acid concentrations in human urine after intensive exposure to styrene. This finding indicates that styrene can also be converted to hippuric acid in man.

Ikeda and Imamura (12) have also determined the biological half-time for styrene by measuring the disappearance of phenylglyoxylic and mandelic acids from urine. They found a value of $7.8 \pm 1.9 \mathrm{~h}$ for mandelic acid. This value agrees well with the half-times $(6.4-9.4 \mathrm{~h}$ ) (table 2) determined during the first postexposure period of our study. A half-time of about $16 \mathrm{~h}$, calculated for the less steep slope of the next 40 -h postexposure period, suggests two phases of excretion.

The observed differences in the halftimes of group I $(9.4 \mathrm{~h})$ and II $(6.4 \mathrm{~h})$ for 


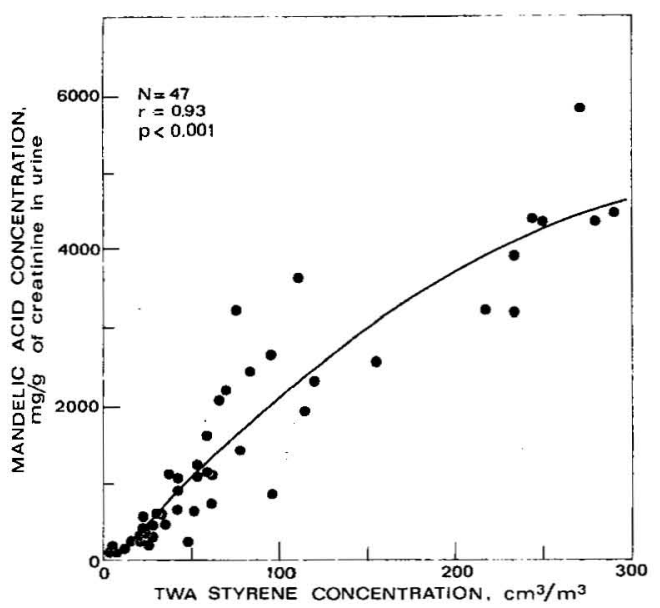

A. Prework mandelic acid concentration accounted for.

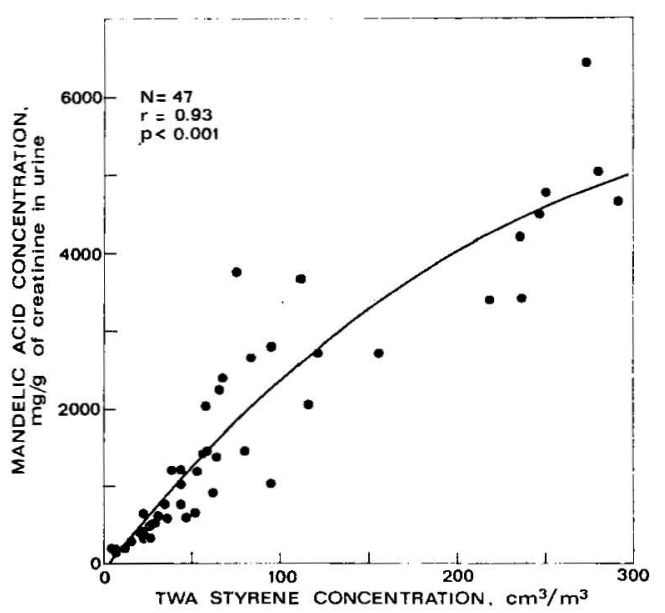

B. Prework mandelic acid concentration unaccounted for

Fig. 2. Correlation between urinary mandelic acid concentration, calculated per gram of creatinine in urine, and the 8-h time-weighted average (TWA) of styrene exposure $\left(\mathrm{cm}^{3} / \mathrm{m}^{3}\right)$. The regression equations were estimated as: A. $y=-120.1+25.46 \mathrm{x}-0.03197 \mathrm{x}^{2} \pm 556.0$; B. $y=-47.2+27.08 x-0.03386 x^{2} \pm 600.0$.

the first postexposure period indicate that the half-times were influenced by the level of styrene exposure. It has been found in animal studies that rat liver is able to increase its capacity to detoxify styrene by means of enzyme induction, especially enhancement of epoxide hydrase and UDP-glucuronosyltransferase activities (17). The same kind of metabolic alterations may occur in man.
Urinary mandelic acid as an indicator of styrene exposure

The elimination of styrene in the form of mandelic acid makes it possible to use the urinary concentration of this acid, collected immediately after a work shift, as an indicator of styrene exposure. However, we found that styrene is not completely eliminated in the 16 - $h$ period between daily exposure at work. When measurements were made on consecutive days, about $30 \%$ of the maximal mandelic acid concentration of the first day was measured in the urine samples taken before work began on the secon'd. It has been proposed that body burden reaches an equilibrium within 2 days and does not increase thereafter if the half-time is less than $12 \mathrm{~h}$, i.e., providing the daily variation of exposure is not great (16). For this reason, we recommend that urine samples be collected for the exposure test on any day other than the first day of the work week. This recommendation is supported by the fact that the amount of mandelic acid corresponding to $100 \mathrm{ppm}$ of styrene did not noticeably differ whether prework urinary mandelic acid concentrations were considered or not (figs. $2 \mathrm{a}$ and b). In the first case the mandelic acid concentration corresponding to $100 \mathrm{ppm}$ of the 8-h TWA of strene exposure was $2,100 \mathrm{mg}$ per gram of creatinine; and in the second, $2,300 \mathrm{mg}$ per gram of creatinine.

The higher correlation between the 8-h TWA of styrene exposure and the concentration of mandelic acid when expressed as milligrams per gram of creatinine than when corrected to a constant specific gravity suggests that the creatinine correction is more reliable for practical use.

\section{REFERENCES}

1. ÅstRAND, I., KILBOM, A., OUVRUM, P., WAHLBERG, I. and VESTERBERG, O. Exposure to styrene: I. Concentration in alveolar air and blood at rest and during exercise and metabolism. Work-environ.health 11 (1974) 69-85.

2. AXELSON, O., FRÖBÄRJ, B. and WEDFELT, U. Kan styrenexposition orsaka cerebroläsionella tillstånd? Läkartidningen 71 (1974) 137-138.

3. BARDODEJ, Z. and BARDODEJOVA, E. Biotransformation of ethylbenzene, styrene 
and alpha-methylstyrene in man. Am. ind. hyg. assoc. j. 31 (1970) 206-209.

4. BUCHET, J., LAUWERYS, R. and ROELS, H. Evaluation de l'exposition des travailleurs au styrène par le dosage de ses métabolites urinaires: les acides mandélique et phénylglyoxylique: $\mathbf{I}$. Technique de dosage des métabolites par chromatographie en phase gazeuse. Arch. mal. prof. med. tra. secur. soc. 35 (1974) 507-512.

5. DANISHEFSKY, J. and WILLHITE, M. The metabolism of styrene in the rat. $J$. biol. chem. 211 (1954) 549-553.

6. EL MASRI, A., SMITH J. and WILLIAMS, $R$. The metabolism of alkylbenzenes: Phenylacetylene and phenylethylene. Biochem. j. 68 (1958) 199-204.

7. ENGSTRÖIM, $K$. and RANTANEN, J. A new gas chromatographic method for determination of mandelic acid in urine. Int. Arch. Arbeitsmed. 33 (1974) 163-167.

8. GAMBERALE, F. and HULTENGREN, M. Exposition för styren. Psykofysiologiska funktioner. Arbete och Hälsa 3 (1973) 4359

9. GERARDE, H. V. and LINDEN, N. J Toxicological studies on hydrocarbons: III. The biochemorphology of the phenylalkanes and phenylalkenes. Arch. ind. health 19 (1959) 403-408.

10. GÓTELL, P., AXELSON, $O$. and LINDELÖF, B. Field studies on human styrene exposure. Work-environ.-health 9 (1972) $76-83$.

11. HÄRKÖNEN, H., KALLIOKOSKI, P., HIETALA, S. and HERNBERG, S. Concentration of mandelic and phenylglyoxylic acid in urine as indicators of styrene exposure. Work-environ.-health 11 (1974) 162-165.
12. IKEDA, M., IMAMURA, T. HAYASHI, M., TABUCHI, T. and HARA, I. Evaluation of hippuric, phenylglyoxylic and mandelic acids in urine as indices of styrene exposure. Int. Arch. Arbeitsmed. 32 (1974) 93-101.

13. KALLIOKOSKI, $P$. and PFAFFLI, $P$. Charcoal sampling method for determining the concentration of styrene in air. Scand. j. work environ. \& health 1 (1975) 193-198.

14. KLIMKOVA-DEUTSCHOVA, E. Neurologische Befunde in der Plastikindustrie bei Styrol-Arbeitern. Int. Arch. Gewerbepathol. Gewerbehyg. 19 (1962) 35-50.

15. LEIBMAN, K. C. Metabolism and toxicity of styrene. Environ. health perspect. 11 (1975) 115-119.

16. LINCH, L. H. Biological monitoring for industrial chemical exposure control. CRC Press, Inc., Cleveland, Ohio 1974, 122 p.

17. PARKKI, M., VAINIO, H. and MARNIEMI, J. Effects of styrene administration on the detoxifying enzymes in rat liver. In: Abstracts: Sixth international congress of pharmacology, Helsinki, Finland July 2025. 1975 , p. 459.

18. PHILIPPE, R., LAUWERYS, R. BUCHET, J. P. and ROELS, $H$. Evaluation de l'exposition des travailleurs au styrène par le dosage de ses métabolites urinaires: les acides mandélique et phénylglyoxylique: II. Application aux travailleurs fabriquant des polyesters. Arch. mal. prof. med. tra. secur. soc. 35 (1974) 631-640.

19. SLOB, A. A new method for determination of mandelic acid excretion at low level styrene exposure. $B r . j$. ind. med. 30 (1973) $390-393$. 